\title{
MINIMUM PENUTUP TITIK DAN MINIMUM PENUTUP SISI PADA GRAF KOMPLIT DAN GRAF BIPARTIT KOMPLIT
}

\author{
Romiana Banjarnahor, Mulyono \\ Jurusan Matematika, FMIPA Medan, Indonesia \\ E-mail:omibanjarnahor@yahoo.com
}

\begin{abstract}
Abstrak
Penelitian ini dilakukan untuk menentukan minimum penutup titik dan minimum penutup sisi pada graf komplit dan graf bipartit komplit. Dengan menentukan kardinalitas dari graf komplit $K_{n}$ dan graf bipartit komplit akan diperoleh minimum penutup titik dan sisi dari graf komplit dan graf bipartit komplit. Berdasarkan hasil pembahasan, langkahlangkah penelitian ini yaitu: 1) Menjelaskan tentang graf komplit dan graf bipartit komplit, 2) Menjelaskan tentang minimum penutup titik dan sisi pada graf komplit dan graf bipartit komplit, 3) Menentukan minimum penutup titik dan sisi pada graf komplit dan graf bipartit komplit, 4) Mencari himpunan minimum penutup titik dan sisi pada graf komplit dan graf bipartit komplit, 5)Menentukan minimum penutup titik dan minimum penutup sisi pada graf komplit dan graf bipartit komplit. Berdasarkan langkah-langkah tersebut maka diperoleh hasil: 1) Minimum penutup titik pada graf komplit dilambangkan dengan $\alpha(G)$ adalah $n-1$ dan untuk minimum penutup sisi pada graf komplit dilambangkan dengan $\alpha_{1}(G)$ sebagai berikut: $\left\{\begin{array}{l}\frac{n}{2}, \text { untuk } n \text { genap } \\ \frac{n+1}{2}, \text { untuk } n \text { ganjil }\end{array}\right.$

Minimum penutup titik pada graf bipartit komplit dilambangkan dengan $\alpha(G)$ adalah $\alpha(G)=\min \left\{\left|V_{1}\right|,\left|V_{2}\right|\right\}$ dan minimum penutup sisi pada graf bipartit komplit dilambangkan dengan $\alpha_{1}(G)=\operatorname{maks}\left\{\left|V_{1}\right|,\left|V_{2}\right|\right\}$.
\end{abstract}

Kata Kunci: penutup titik, penutup sisi, minimum, graf komplit, graf bipartit komplit

\begin{abstract}
This study was conducted to determine the minimum cover and minimum edge cover complete and complete bipartite graph. By determining the cardinality of complete graph and complete bipartite graph. Based on the results of the discussion, the steps in this research are: 1) Explaining complete graph and complete bipartite graph, 2) Describe the minimum vertex cover and edge in the graph complete and complete bipartite graph,
\end{abstract}


3) Determine the minimum vertex cover and edge in the graph complete and complete bipartite graph,4) for the set minimum vertex cover and edge in the graph complete and complete bipartite graph, 5) Determine the minimum vertex cover and edge on complete graph and complete bipartite graph. Based on these measures the obtained results: 1) Minimum vertex cover on the graph complete is denoted by $\alpha(G)$ is $n-1$ and minimum edge cover on the complete graph denoted by $\alpha_{1}(G)$ is $\left\{\begin{array}{l}\frac{n}{2}, \text { for } n \text { even } \\ \frac{n+1}{2}, \text { for } n \text { odd }\end{array}\right.$,2) Minimum vertex cover on the complete bipartite graph denoted by $\alpha(G)=\min \left\{\left|V_{1}\right|,\left|V_{2}\right|\right\}$ and minimum edge cover on the complete bipartite graph denoted by $\alpha_{1}(G)=\max$ $\left\{\left|V_{1}\right|,\left|V_{2}\right|\right\}$.

Keyword: vertex cover, edge cover, minimum, complete graph, complete bipartite graph

\section{Pendahuluan}

Dewasa ini, ilmu pengetahuan sudah banyak digunakan untuk memecahkan berbagai permasalahan di dalam kehidupan manusia. Seiring dengan bantuan matematika permasalahan tersebut menjadi lebih mudah dipahami, lebih mudah dipecahkan atau bahkan dapat ditunjukkan bahwa suatu persoalan tidak memiliki penyelesaian. Salah satu konsep matematika yang banyak digunakan yaitu konsep teori graf pada matematika diskrit. Dalam sehari-hari banyak permasalahan-permasalahan yang memerlukan pemecahan. Dengan menggunakan rumusan atau model teori graf yang tepat, suatu permasalahan menjadi semakin jelas, sehingga mudah menganalisisnya. Teori graf merupakan pokok bahasan yang sudah tua usianya namun memiliki banyak terapan sampai saat ini.

Graf adalah cabang ilmu matematika yang pertama kali diperkenalkan oleh matematikawan Swiss yang bernama Leonard Euler pada tahun 1736, yaitu saat penyelesaian jembatan Konigsberg. Graf digunakan untuk mempresentasikan objek-objek diskrit dan hubungan antara objek-objek tersebut. Representasi visual dari graf adalah dengan menyatakan objek dinyatakan sebagai noktah, bulatan, atau titik sedangkan hubungan antara objek dinyatakan dengan sisi [1].

Diantara sekian banyak konsep dalam teori graf, konsep penutup titik dan penutup sisi pada graf merupakan masalah yang akan penting untuk diteliti khususnya bagi yang tertarik dengan penerapan graf. Graf $G$ adalah himpunan pasangan $(V, E)$ dengan $V$ adalah himpunan tidak kosong dan berhingga yang disebut titik dan $E$ adalah himpunan (mungkin kosong) pasangan tak berurut titik-titik di $V$ yang disebut sisi. 
Himpunan titik $G$ dinotasikan dengan $V(G)$ dan himpunan sisi $G$ dinotasikan dengan $E(G)$.

Suatu titik dan sisi dikatakan saling menutup pada graf $G$ jika titik dan sisi tersebut terkait langsung di $G$. Penutup titik di $G$ merupakan himpunan dari titik $V(G)$ sedemikian sehingga setiap sisi di $G$ terkait langsung dengan paling sedikit satu titik di $G$. Kardinalitas adalah bilangan yang menyatakan berapa banyak anggota dalam sebuah himpunan objek. Kardinalitas minimum penutup titik pada graf $G$ disebut bilangan penutup titik dan dilambangkan dengan $\alpha(G)$. Penutup sisi dari graf $G$ adalah himpunan dari sisi $E(G)$ sedemikian sehingga setiap titik di $G$ terkait langsung dengan paling sedikit satu sisi di $G$. Kardinalitas minimum penutup sisi pada graf $G$ disebut bilangan penutup sisi dan dilambangkan dengan $\alpha_{1}(\mathrm{G})$. Hal yang menarik untuk dikaji mengenai penutup titik dan penutup sisi adalah penentuan minimum penutup titik $\alpha(G)$ dan minimum penutup sisi $\alpha_{1}(\mathrm{G})$. Sejauh ini penelitian tentang penentuan minimum penutup titik $\alpha(\mathrm{G})$ dan minimum penutup sisi $\alpha_{1}(\mathrm{G})$ masih jarang dilakukan penelitian [2, 3].

Beberapa penelitian yang mengkaji tentang Minimum Penutup Titik dan Penutup Sisi, yaitu oleh Nurul Hijriyah dan Wahyu H. Irawan yang berjudul “ Titik dan Sisi Penutup Minimal pada Graf Bintang $(m)_{c} S_{n}^{k}$ dan Graf Roda $(m)_{c} W_{n}^{k}$,'. Penelitian tersebut membahas tentang mininum penutup titik dan minimum penutup sisi pada graf bintang dan graf roda. Tulisan hasil Penelitian ini memaparkan bagaimana rumus umum untuk minimum penutup titik dan minimum penutup sisi pada Graf Bintang $(m)_{c} S_{n}^{k}$ dan Graf Roda $(m)_{c} W_{n}^{k}$ yang berbeda serta berlaku secara umum pada graf bintang dan graf roda tersebut.

Penelitian lain tentang penutup graf pernah juga dilakukan terlebih dahulu oleh Babak Behsaz yang berjudul " Minimum vertex covers of Generalized Petersen Graphs". Pada perkembangannya penelitian tentang minimum penutup titik dan penutup sisi terus dilanjutkan untuk membuktikan tentang penutup titik dan sisi pada graf yang berbeda. Berdasarkan hasil beberapa penelitian yang telah mengkaji penutup titik pada graf tersebut mengasilkan rumusan yang berbeda dari setiap graf.

Dan karena adanya perbedaan setiap rumusan penutup titik dan penutup sisi pada masing-masing graf tersebut yang akan berlaku secara umum untuk masing-masing graf yang diteliti tersebut, maka penulis tertarik untuk mengkaji penutup titik dan penutup sisi pada graf yang berbeda. Penulis tertarik untuk mengkaji penutup titik dan sisi pada graf sederhana yaitu pada graf komplit dan graf bipartit untuk membuktikan rumusan umum penutup titik dan sisi dapat berlaku juga untuk graf komplit dan graf bipartit komplit 
seperti saran dari penelitian sebelumnya. Permasalahan pada tulisan ini adalah : (1) Bagaimana menentukan berapa bilangan minimum penutup titik dan minimum penutup sisi pada graf komplit, (2) Bagaimana menentukan berapa bilangan minimum penutup titik dan minimum penutup sisi pada graf bipartit komplit ? Untuk menyelesaikan permasalahan ini penulis membatasi masalah yaitu pada :

Minimum Penutup titik dan minimum penutup sisi pada graf komplit $K_{n}$ dan graf bipartit komplit $K_{m, n}$.

\section{Metode Penelitian}

Adapun langkah-langkah yang digunakan dalam prosedur penelitian ini adalah:

1. Menjelaskan tentang graf komplit dan graf bipartit komplit

2. Menjelaskan tentang Minimum penutup titik dan minimum penutup sisi serta kardinalitas minimum.

3. Menjelaskan rumus yang akan digunakan untuk menentukan minimum penutup titik dan minimum penutup sisi pada graf komplit dan graf bipartit komplit.

4. Mencari himpunan penutup titik dan himpunan penutup sisi pada graf komplit dan graf bipartit komplit

5. Menentukan kardinalitas minimum dari himpunan penutup titik dan himpunan penutup sisi pada graf komplit dan graf bipartit komplit.

6. Menarik Kesimpulan

\section{Hasil Dan Pembahasan}

untuk $\boldsymbol{n}=\mathbf{4}$
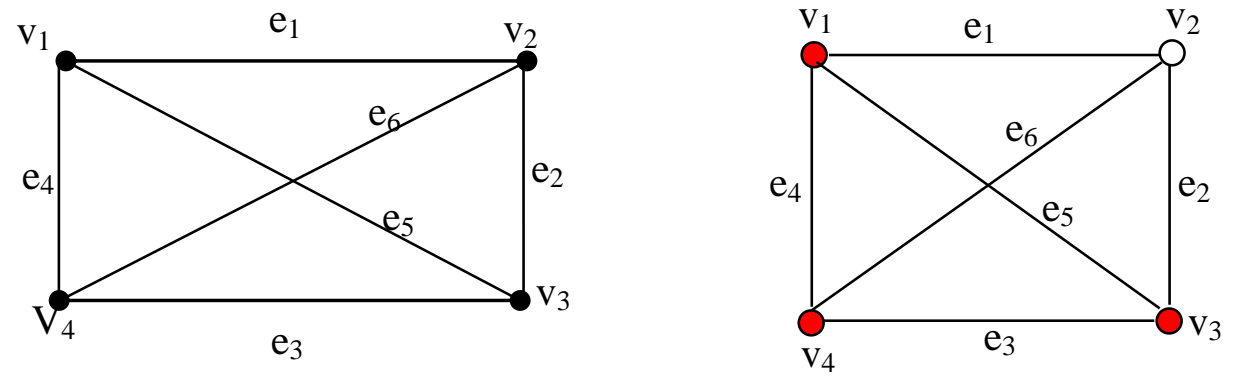

Gambar 1. Graf Komplit $\boldsymbol{K}_{\mathbf{4}}$ 
Minimum penutup titik ditandai dengan warna merah

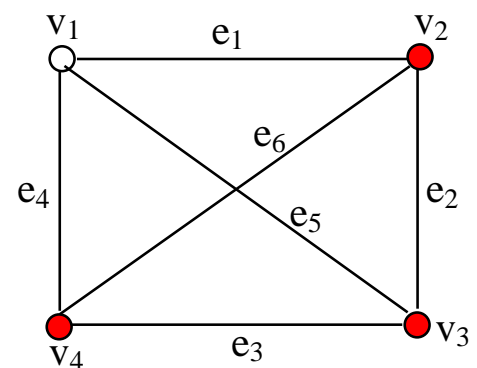

Gambar 2 Minimum Penutup Titik pada graf komplit $\boldsymbol{K}_{\mathbf{4}}$

Himpunan penutup titik pada graf komplit $K_{4}$ adalah : $\left\{v_{1}, v_{2}, v_{3}, v_{4}\right\}$

Kardinalitas yang terbentuk untuk $n=4$ yaitu $K_{4}:\left\{v_{1}, v_{2}, v_{3}\right\},\left\{v_{2}, v_{3}, v_{4}\right\},\left\{v_{3}, v_{4}, v_{1}\right\}$, $\left\{v_{4}, v_{1}, v_{2}\right\}$. Jadi minimum penutup titik pada graf komplit dengan $n=4$ adalah $\alpha(G)=3$.

Tabel 1. Minimum Penutup Titik pada Graf Komplit $\boldsymbol{K}_{\boldsymbol{n}}$

\begin{tabular}{|c|c|}
\hline Graf $\left(K_{n}\right)$ & $\alpha\left(K_{n}\right)$ \\
\hline$K_{2}$ & 1 \\
\hline$K_{3}$ & 2 \\
\hline$K_{4}$ & 3 \\
\hline$K_{5}$ & 4 \\
\hline$K_{6}$ & 5 \\
\hline$\ldots$ & $\cdots$ \\
\hline$K_{n}$ & $n-1$ \\
\hline
\end{tabular}

Setelah melihat pola diatas untuk menghitung minimum penutup titik pada graf komplit adalah $K_{n}=n-1$ yang akan dirumuskan ke dalam lemma. Lemma tersebut diperoleh dari teorema graf komplit.

\section{Teorema}

Banyaknya sisi dalam suatu graf komplit dengan $\mathrm{n}$ titik adalah $\frac{n(n-1)}{2}$ buah 


\section{Bukti:}

Misalkan $G$ adalah suatu graf komplit dengan $n$ titik $v_{1}, v_{2}, \ldots, v_{n}$. Ambil sembarang titik (sebutlah $v_{1}$ ). Karena $G$ merupakan graf komplit, maka $v_{1}$ dihubungkan dengan $(n-1)$ titik lainnya $\left(v_{2}, v_{3}, \ldots, v_{n}\right)$. Jadi ada $(n-1)$ buah sisi. Selanjutnya ambil sembarang titik kedua (sebutlah $v_{2}$ ). Karena $G$ adalah graf komplit, maka $v_{2}$ juga dihubungkan dengan semua titik sisanya $\left(v_{1}, v_{3}, \ldots, v_{n}\right)$, sehingga ada $(n-1)$ buah sisi yang berhubungan dengan $v_{2}$. Salah satu sisi tersebut menghubungkan $v_{2}$ dengan $v_{1}$. Sisi ini sudah diperhitungkan pada waktu menghitung banyaknya sisi yang berhubungan dengan $v_{1}$. Jadi, ada $(n-2)$ sisi yang belum diperhitungkan.

Proses dilanjutkan dengan menghitung banyaknya sisi yang berhubungan dengan $v_{3}, v_{4}, \ldots, v_{n-1}$ dan yang belum diperhitungkan sebelumnya. Banyak sisi yang didapat berturut-turut adalah: $(n-3),(n-4), \ldots, 3,2,1$. Jadi secara keseluruhan terdapat $(n-1)+(n-2)+(n-3)+\ldots+2+1=\frac{n(n-1)}{2}$ buah sisi.

Berdasarkan teorema tersebut diperoleh sebuah lemma dalam menentukan minimum penutup titik pada graf komplit, sebegai berikut:

\section{Lemma 4.1.1}

Misalkan $K_{n}$ adalah graf komplit, maka minimum penutup titik dari graf komplit $K_{n}$ adalah $\alpha\left(K_{n}\right)=n-1$.

\section{Bukti :}

Misalkan $V\left(K_{n}\right)=\left\{v_{i} \leq i \leq n\right\}$. Misalkan $C$ adalah penutup titik $K_{n}$. Klaim $C=\left\{v_{i} \mid 1 \leq i \leq n-1\right\}$. Akan ditunjukkan bahwa $C$ adalah minimum penutup titik. Berdasarkan teorema graf komplit $\left|V\left(K_{n}\right)\right|=\frac{n(n-1)}{2}$, sisi-sisi yang terkait dengan titik $v_{1}$ adalah $v_{1} v_{2}, v_{1} v_{3}, v_{1} v_{4}, \ldots, v_{1} v_{n}, v_{n}$ sehingga $v_{1}$ menutup $n-1$ sisi $k_{n}$. Sisi-sisi yang terkait dengan titik $v_{2}$ adalah $v_{2} v_{1}, v_{2} v_{3}, v_{2} v_{4}, \ldots, v_{2} v_{n}, v_{n}$ sehingga $v_{2}$ menutup $(n-1)$ sisi $k_{n}$. Tetapi karena sisi $v_{2} v_{1}$ sudah ditutup oleh $v_{1}$ maka titik $v_{2}$ menutup $n-2$ sisi $k_{n}$. Sisi-sisi yang terkait dengan titik $v_{n-1}$ adalah $v_{n-1} v_{1}, \ldots, v_{n-1} v_{n}$ karena sisi $v_{n-1} v_{1}, v_{n-1} v_{2}, v_{n-1} v_{3}, \ldots, v_{n-2} v_{n}$ telah tertutup oleh titik $v_{1}, v_{2}, v_{3}, \ldots, v_{n-2}$ maka titik $v_{n-1}$ menutup $n-(n-1)$ sisi. Demikian juga dengan titik $v_{n}$, sisi-sisi yang terkait pada titik $v_{n}$ adalah $v_{n} v_{1}, v_{n} v_{2}, v_{n} v_{3}, \ldots v_{n} v_{n-1}$ sehingga $v_{n}$ menutup sisi $v_{n} v_{j}, j=$ $1,2,3, \ldots, n$ dan $j \neq n$. Tetapi karena sisi $v_{n} v_{1}, v_{n} v_{2}, v_{n} v_{3}, \ldots v_{n} v_{n-1}$ sudah tertutup oleh titik $v_{1}, v_{2}, v_{3}, \ldots, v_{n-1}$ maka titik $v_{n}$ tidak menutup sisi $K_{n}$. Sehingga diperoleh banyaknya sisi yang tertutup oleh titik di $\mathrm{C}$ adalah: 


$$
\begin{aligned}
(n-1)+(n-2)+(n & -3)+\cdots+(n-(n-1)) \\
& =n(n-1)-(1+2+3+\cdots+n-1) \\
& =\frac{n(n-1)}{2}
\end{aligned}
$$

Dengan demikian semua sisi $K_{n}$ telah tertutup oleh titik-titik di $C$, karena ada satu titik yang tidak menutup semua titik dikarenakan sudah ditutup oleh titik yang lainnya maka diperoleh minimum penutup titik $|G|=n-1$.

Berdasarkan bukti diatas maka diperoleh $\alpha\left(K_{n}\right)=|G|=n-1$.

\section{Minimum Penutup Sisi pada Graf Komplit $K_{n}$}

1 untuk $n=4$

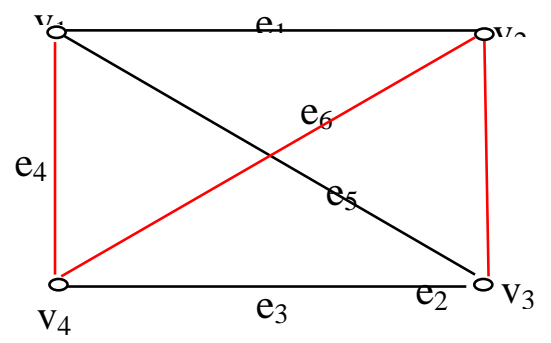

Gambar 3 Minimum Penutup Sisi $\boldsymbol{K}_{\mathbf{4}}$

Himpunan penutup sisi pada graf Komplit $n=4$ yaitu $\left(K_{4}\right):\left\{e_{1}, e_{2}, e_{3}, e_{4}, e_{5}, e_{6}\right\}$. Kardinalitas minimum penutup sisi pada graf Komplit untuk $K_{4}$ adalah $\left\{e_{2}, e_{4}, e_{6}\right\}$. Jadi

\begin{tabular}{|c|c|}
\hline $\operatorname{Graf}\left(K_{n}\right)$ & $\alpha_{1}\left(K_{n}\right)$ \\
\hline$K_{3}$ & 2 \\
\hline$K_{4}$ & 2 \\
\hline$K_{5}$ & 3 \\
\hline$K_{6}$ & 3 \\
\hline$\ldots$ & $\ldots$ \\
\hline$K_{n}$ & $\begin{array}{l}\frac{n}{2}, \text { untuk } n \text { genap } \\
\frac{n+1}{2}, \text { untuk } n \text { ganjil }\end{array}$ \\
\hline
\end{tabular}
minimum penutup sisi pada graf Komplit $\alpha_{1}\left(K_{4}\right)=3$.

Tabel 2 Minimum Penutup Sisi pada Graf Komplit $\boldsymbol{K}_{\boldsymbol{n}}$

Setelah melihat pola diatas untuk menghitung berapa minimum penutup sisi pada graf komplit akan dirumuskan kedalam lemma sebagai berikut: 


\section{Lemma 4.1.2}

Misalkan $K_{n}$ adalah graf komplit, maka minimum penutup sisi dari graf komplit $K_{n}$ adalah:

$$
\alpha_{1}=\left\{\begin{array}{c}
\frac{n}{2}, \text { untuk } n \text { genap } \\
\frac{n+1}{2}, \text { untuk } n \text { genap }
\end{array}\right.
$$

\section{Bukti:}

Andaikan $Q$ adalah penutup sisi $K_{n}$. Klaim $Q=\left\{e_{i} \mid 1 \leq i \leq n-1, i\right.$ ganjil $\}$. Akan ditunjukkan bahwa $Q$ aladah minimum penutup sisi pandang sikel luar graf komplit yaitu $Q: v_{1}, v_{2}, v_{3}, v_{4}, \ldots, v_{n}, v_{n-1}$.

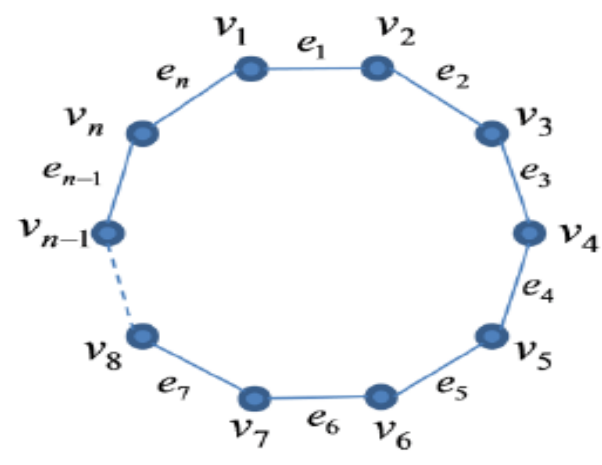

\section{Gambar 4. Sikel luar graf Komplit}

Sisi $e_{i}$ merupakan sisi yang menghubungkan titik $v_{i}$ dan $v_{i+1}$. Sisi $e_{i}$ dipilih oleh $Q$ maka $e_{1}$ menutup titik $v_{1}$ dan $v_{2}$, sisi $e_{2}$ menutup titik $v_{2}$ dan $v_{3}$ tetapi karena titik $v_{2}$ telah tertutup oleh sisi $e_{1}$ maka sisi $e_{2}$ tidak dipilih oleh $Q$. Seterusnya sampai sisi $e_{n-2}$ dipilih oleh $Q$ maka $e_{n-2}$ menutup titik $v_{n-2}$ dan $v_{n-1}$. Sisi $e_{n}$ tidak dipilih oleh $Q$ karena titik $v_{1}$ dan titik $v_{2}$ telah tertutup oleh sisi $e_{1}$ dan $e_{n-2}$. Demikian juga dengan sisi-sisi dengan label berindeks genap lainnya tidak dipilih oleh $Q$ karena semua titik di $V\left(K_{n}\right)$ telah tertutup oleh sisi $e_{i}, i$ ganjil sehingga diperoleh penutup sisi

$Q=\left\{e_{1}, e_{2}, e_{3}, e_{4}, e_{5}, \ldots ., e_{n-1}\right\}$, sehingga diperoleh:

$Q=\left\{e_{1}, e_{2}, e_{3}, e_{4}, e_{5}, \ldots ., e_{n-1} e_{n}\right\}$ dengan melihat indeks pertama didapat barisan $1,3,5, \ldots, n-1$ utuk ganjil atau $2,4,6, \ldots \ldots, n$ untuk genap. Dari barisan tersebut didapat barisan aritmatika.

Akan dihitung minimum penutup sisi pada graf komplit: 


\section{$\boldsymbol{n}=$ genap}

Dengan suku awal $a=2$ dan beda $(b)=2$. Diperoleh rumus umum suku ke $n$ sebagai berikut:

Diketahui $2,4,6, \ldots \ldots, n$

misalkan $U_{n}=U_{q}$ dengan mengganti $n=q . U_{q}=n$

Diketahui rumus aritmatika adalah :

$U_{n}=a+(n-1) b$ dengan menggunakan pemisalan diatas didapat:

$U_{q}=a+(q-1) b$

$U_{q}=2+(q-1) 2$

$U_{q}=2 q$

Dimisalkan sebelumnya $U_{q}=n$. Substitusi $U_{q}=2 q$ ke persamaan $U_{q}=n$.

$2 q=n$

$q=\frac{n}{2}$

Jadi minimum penutup sisi graf komplit $\alpha_{1}\left(K_{n}\right)=\frac{n}{2}$, untuk $n$ genap.

\section{$n=$ ganjil}

Andaikan $Q$ adalah penutup sisi $K_{n}$. Klaim $Q=\left\{e_{i} \mid 1 \leq i \leq n-1, i\right.$ ganjil $\}$, e merupakan sisi. Pandang sikel luar graf komplit yaitu :

$C: v_{1}, v_{2}, v_{3}, v_{4}, \ldots ., v_{n}, v_{n-1}$ pada gGambar 4. Sisi $e_{1}$ dipilih oleh $Q$ maka $e_{1}$ menutup titik $v_{1}$ dan $v_{2}$. Jika sisi $e_{2}$ dipilih oleh $Q$ maka sisi $e_{2}$ menutup titik $v_{2}$ dan $v_{3}$ tetapi karena titik $v_{2}$ telah tertutup oleh sisi $e_{1}$ maka sisi $e_{2}$ tidak dipilih oleh $Q$. Sisi $e_{3}$ dipilih oleh $Q$ maka $e_{3}$ menutup titik $v_{3}$ dan $v_{4}$. Demikian juga dengan sisi-sisi dengan label indeks ganjil tidak dipilih oleh $Q$.

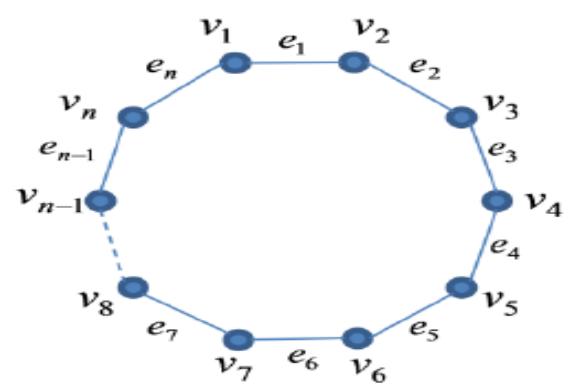

Gambar 5. Sikel luar graf Komplit 
Dapat dibuat himpunan minimum penutup sisi graf komplit $K_{n}$ berikut: $Q=$ $\left\{e_{1} e_{2}, e_{3} e_{5}, \ldots, e_{n-2} e_{n-1}, e_{n-1} e_{n}\right\}$

Dengan melihat indeks pertama didapat barisan $1,3,5, \ldots, n-1$. Dari barisan tersebut didapat barisan aritmatika. Dalam perhitungan ini $e_{n-1} e_{n}$ tidak diikutkan terlebih dahulu untuk mempermudah perhitungan. Dari barisan aritmatika diatas diperoleh suku awal $a=1$ dan $\operatorname{bed} a(b)=2$. Diperoleh rumus umum suku ke $n$ sebagai berikut:

Diketahui $1,3,5, \ldots . ., n-2$

misalkan $U_{n}=U_{q}$ dengan mengganti $n=q$.

$U_{q}=n-2$

Diketahui rumus aritmatika adalah :

$U_{n}=a+(n-1) b$ dengan menggunakan pemisalan diatas didapat:

$U_{q}=a+(q-1) b$

$=1+(q-1) 2$

$U_{q}=2 q-1$

Sebelumnya telah dimisalkan $U_{q}=n-2$. Substitusi $U_{q}=2 q-1$ ke persamaan $U_{q}=n-2$.

$$
\begin{gathered}
2 q-1=n-2 \\
2 q=n-2+1 \\
q=\frac{n-1}{2}
\end{gathered}
$$

Karena $e_{n-1} e_{n}$ belum dihitung, maka sekarang akan diikut sertakan dalam perhitungan sebagai berikut:

$$
q=\frac{n-1}{2}+1
$$

$q=\frac{n+1}{2}$

Jadi minimum penutup sisi graf komplit $\alpha_{1}\left(K_{n}\right)=\frac{n+1}{2}$, untuk $n$ ganjil.

Dari uraian diatas dapat disimpulkan bahwa:

$\alpha_{1}\left(K_{n}\right)=\left\{\begin{array}{c}\frac{n}{2}, \text { untuk } n \text { genap } \\ \frac{n+1}{2}, \text { dengan } n \text { ganjil }\end{array}\right.$

4.1.2 Minimum Penutup Titik dan Sisi pada graf Bipartit Komplit

a. Minimum Penutup Titik pada graf Bipartit Komplit $\boldsymbol{K}_{\boldsymbol{m}, \boldsymbol{n}}$ 
Definisi Graf Bipartit Komplit

Sebuah graf sederhana $G$ disebut bipartit komplit jika titik $V$ dapat dipartisi menjadi dua himpunan saling lepas $V_{1}$ dan $V_{2}$ sehingga setiap sisi dalam graf menghubungkan titik dalam $V_{1}$ dan titik di $V_{2}$ saling terhubung.

Dalam hal ini $V_{1}:\left\{v_{1}, v_{2}, v_{3}, \ldots, v_{n}\right\}$ dan $V_{2}:\left\{w_{1}, w_{2}, w_{3}, \ldots, w_{n}\right\}$

untuk $m=n$

$>K_{2,2}$, dengan $m=2$ dan $n=2$
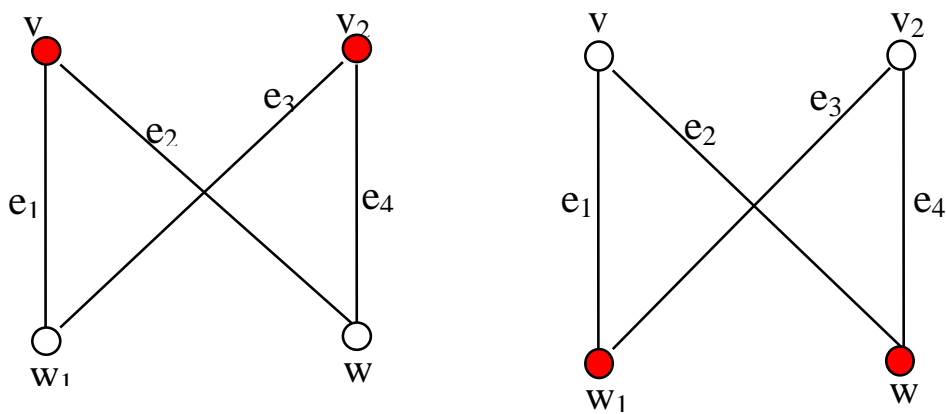

Gambar 6 Minimum Penutup Titik pada Graf Bipartit $\boldsymbol{K}_{\mathbf{2 , 2}}$

Himpunan penutup titik pada graf bipartit komplit $K_{2,2}$ yaitu $\left\{v_{1}, v_{2}, w_{1}, w_{2}\right\}$. Kardinalitas penutup titik pada graf bipartit komplit $K_{2,2}$ yaitu: $\left\{v_{1}, v_{2}\right\},\left\{w_{1}, w_{2}\right\}$. Jadi minimum penutup titik pada graf bipartit komplit $\alpha\left(K_{2,2}\right)=2$

untuk $\boldsymbol{m}<n$

$>K_{1,2}$ dengan $m=1$ dan $n=2$

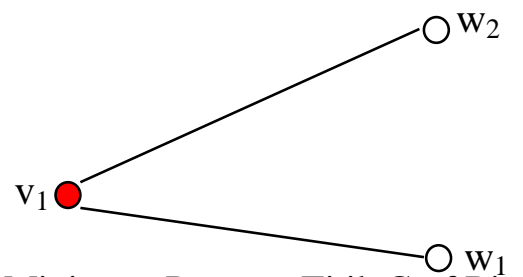

Gambar 7 Minimum Penutup Titik Graf Bipartit Komplit $\boldsymbol{K}_{\mathbf{1 , 2}}$

Himpunan penutup titik pada graf bipartit komplit $K_{1,2}:\left\{v_{1}, w_{1}, w_{2},\right\}$. Kardinalitas penutup titik pada graf bipartit komplit $K_{1,2}:\left\{v_{1}\right\}$. Jadi minimum penutup titik pada graf bipartit komplit $\alpha\left(K_{1,2}\right)=1$

untuk $\boldsymbol{m}>n$

$>K_{2,1}$ dengan $m=2$ dan $n=1$ 


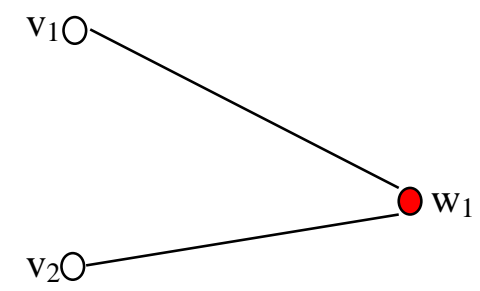

Gambar 8 Minimum Penutup Titik pada Graf Bipartit Komplit $\boldsymbol{K}_{\mathbf{2 , 1}}$

Himpunan penutup titik pada graf bipartit komplit $K_{1,2}\left\{v_{1}, v_{2}, w_{1}\right\}$. Kardinalitas penutup titik pada graf bipartit komplit $K_{2,1}$ adalah $\left\{w_{1}\right\}$. Jadi minimum penutup titik pada graf bipartit komplit $\alpha\left(K_{2,1}\right)=1$ Dari pola yang terbentuk tersebut, maka akan dirumuskan kedalam sebuah lemma dan dibuktikan kebenarannya.

\section{Lemma 4.2.1}

Ukuran minimum penutup titik pada graf bipartit komplit $K_{m, n}$ dengan partisi $\left(V_{1}, V_{2}\right)$ dimana $\left|V_{1}\right|=v_{1}$ dan $\left|V_{2}\right|=v_{2}$ adalah:

$\alpha\left(K_{m, n}\right)=\min \left\{\left|V_{1}\right|,\left|V_{2}\right|\right\}$

\section{Bukti:}

Misalkan $K_{m, n}$ graf bipartit komplit dengan partisi

$V_{1}=\left\{v_{1 i} \mid 1 \leq 1 i \leq v_{1}\right\}$ dan $V_{2}=\left\{v_{2 i} \mid 1 \leq 2 i \leq v_{2}\right\}$.

Dibagi menjadi 3 kasus, yakni: Misalkan $K_{m, n}$ graf bipartit komplit dengan partisi $V_{1}=\left\{v_{1 i} \mid 1 \leq 1 i \leq v_{1}\right\}$ dan $V_{2}=\left\{v_{2 i} \mid 1 \leq 2 i \leq v_{2}\right\}$. Dibagi menjadi 3 kasus, yakni:

\section{1. $\quad$ pada saat $v_{1}=v_{2}$}

Andaikan $C$ adalah penutup titik dari $K_{m, n}$. Klaim $C=\left\{v_{1 i} \mid 1 \leq 1 i \leq v_{1}\right\}$. Akan ditunjukkan bahwa $C$ adalah minimum penutup titik. Berdasarkan definisi graf bipartit komplit setiap titik dilain partisi akan saling berhubungan langsung, sedangkan titik yang berada dalam satu partisi tidak saling berhubungan langsung. Akibatnya titik $v_{1}$ menutup $n$ sisi dari $K_{m, n}$, titik $v_{2}$ menutup $n$ sisi dari $K_{m, n}$, titik $v_{m}$ menutup $n$ sisi dari $K_{m, n}$ sehingga diperoleh titik $v_{i}$ menutup $n . m$ sisi dari $K_{m, n}$ demikian juga dengan titik $w_{i}$ menutup n.m sisi dari $K_{m, n}$. Semua sisi pada $K_{m, n}$ telah tertutup oleh titik-titik di $C$. $C$ merupakan minimum penutup titik dari $K_{m, n}$. Diperoleh minimum penutup titik pada graf bipartit komplit $K_{m, n}, v_{1}=v_{2}$ adalah $\alpha\left(K_{m, n}\right)=|C|=\left|V_{1}\right|=v_{1}$. 


\section{2. atau pada saat $v_{1}<v_{2}$}

Andai $C$ adalah penutup titik $K_{m, n}$. Akan ditunjukkan bahwa $C$ adalah minimum penutup titik. Berdasarkan definisi graf bipartit komplit setiap titik di lain partisi saling berhubungan langsung, sedangkan titik yang berada dalam satu partisi tidak saling berhubungan lagsung. Jika titik di $V_{2}$ dipilih oleh $C$ maka $v_{1}$ menutup $n$ sisi $K_{m, n}$, titik $v_{2}$ menutup $n$ sisi $K_{m, n}$ dan seterusnya sampai titik $v_{m}$ menutup $n$ sehingga diperoleh titik $v_{1 i}$ menutup $v_{2} . v_{1}$ sisi $K_{m, n}$. Demikian juga titik di $V_{1}$ dipilih oleh $C$ maka $v_{2 i}$ menutup $v_{1} \cdot v_{2}$ sisi $K_{m, n}$. Karena $v_{1}<v_{2}$ pilih $C=\left\{v_{1 i} \mid 1<i \leq v_{1}\right\}$ sebagai minimum penutup titik maka diperoleh titik minimum penutup titik pada graf bipartit komplit $K_{m, n}, v_{1}<v_{2}$ adalah $\alpha\left(K_{m, n}\right)=|C|=\left|V_{1}\right|=v_{1}$

\section{3. atau pada saat $v_{1}>v_{2}$}

Andaikan $C$ adalah penutup titik $K_{m, n}$. Akan ditunjukan bahwa $C$ adalah minimum penutup titik. Berdasarkan definisi graf bipartit komplit setiap titik di lain partisi akan saling berhubungan langusung, sedangkan titik yang satu partisi tidak saling berhubungan langsung. Jika titik $v_{i}$ dipilih oleh $C$ maka $v_{1}$ menutup $n$ sisi dari $K_{m, n}$, dan seterusnya sampai $v_{m}$ menutup $n$ sisi dari $K_{m, n}$ sehingga diperoleh titik $v_{i}$ menutup $v_{1} \cdot v_{2}$ sisi dari $K_{m, n}$. Demikian juga jika titik $w_{i}$ dipilih oleh $C$ maka $w_{i}$ menutup $v_{2} \cdot v_{1}$ sisi dari $K_{m, n}$. Karena $v_{1}>v_{2}$, pilih $C=\left\{v_{2 i} \mid 1 \leq i \leq v_{2}\right\}$ sebagai minimum penutup titik. Diperoleh minimum penutup titik pada graf bipartit komplit $K_{m, n}, v_{1}>v_{2}$ adalah $\alpha\left(K_{m, n}\right)=|C|=$ $\left|V_{1}\right|=v_{1}$.

Berdasarkan pembuktian untuk minimum penutup titik yang dibagi menjadi 3 bagian yaitu persamaan $1,2,3$ diperoleh $\alpha\left(K_{m, n}\right)=\min \left\{\left|V_{1}\right|,\left|V_{2}\right|\right\}$.

\section{b. Minimum Penutup Sisi Graf Bipartit Komplit $K_{m, n}$}

Untuk $\boldsymbol{m}=\boldsymbol{n}$

$>m=2 \operatorname{dan} n=2$ 


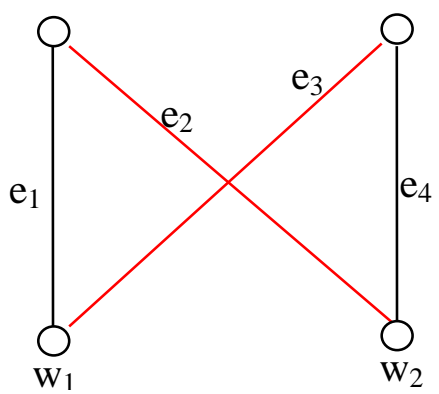

Gambar 9 Minimum Penutup Sisi Graf Bipartit Komplit $\boldsymbol{K}_{\mathbf{2 , 2}}$

Himpunan penutup sisi pada graf bipartit komplit $K_{2,2}$ yaitu $\left\{e_{1}, e_{2}, e_{3}, e_{4}\right\}$. Kardinalitas penutup sisi pada graf bipartit komplit $K_{2,2}$ adalah $\left\{e_{2}, e_{3}\right\}$. Jadi minimum penutup sisi pada graf bipartit komplit $\alpha_{1}\left(K_{2,2}\right)=2$.

\section{Untuk $\boldsymbol{m}<n$}

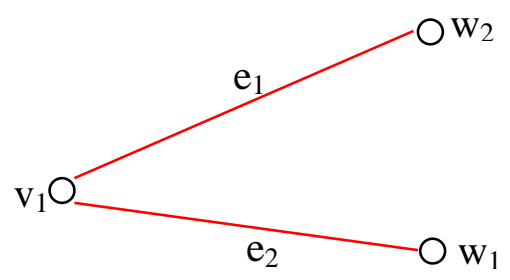

Gambar 10 Minimum Penutup Sisi

\section{Graf Bipartit Komplit $\boldsymbol{K}_{\mathbf{1}, 2}$}

Himpunan penutup sisi pada graf bipartit komplit $K_{1,2}$ yaitu : $\left\{e_{1}, e_{2}\right\}$. Kardinalitas penutup sisi pada graf bipartit komplit $K_{1,2}$ adalah $\left\{e_{1}, e_{2}\right\}$. Jadi minimum penutup sisi pada graf bipartit komplit $\alpha_{1}\left(K_{1,2}\right)=2$

$>$ Untuk $\boldsymbol{m}>n$

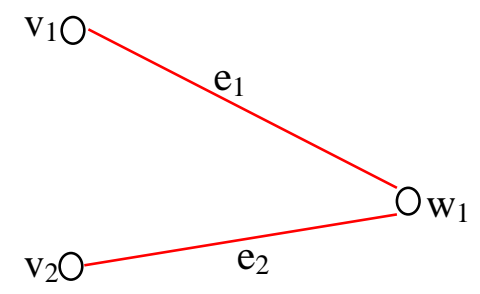

Gambar 11 Minimum Penutup Sisi Graf Bipartit Komplit $\boldsymbol{K}_{\mathbf{2 , 1}}$ 
Himpunan penutu sisi pada graf bipartit komplit $K_{2,1}$ yaitu $:\left\{e_{1}, e_{2}\right\}$. Kardinalitas penutup sisi pada graf bipartit komplit $K_{2,1}$ adalah $\left\{e_{1}, e_{2}\right\}$. Jadi minimum penutup sisi pada graf bipartit komplit $\alpha_{1}\left(K_{2,1}\right)=2$. Dari pola yang terbentuk tersebut, maka akan dirumuskan kedalam sebuah lemma dan buktikan kebenarannya.

\section{Lemma 4.2.2}

Misalkan $K_{m, n}$ adalah graf bipartit komplit, maka minimum Penutup sisi pada graf bipartit komplit $K_{m, n}$ adalah:

$$
\boldsymbol{\alpha}_{\mathbf{1}}\left(K_{\boldsymbol{m}, \boldsymbol{n}}\right)=\operatorname{maks}\left\{\left|V_{1}\right|,\left|V_{2}\right|\right\}
$$

\section{Bukti:}

Misal $K_{m, n}$ graf bipartit komplit dengan partisi $V_{1}=\left\{v_{1 i} \mid 1 \leq i \leq v_{1}\right\}$ dan $V_{2}=$ $\left\{v_{2 i} \mid 1 \leq i \leq v_{2}\right\}$. Dibagi menjadi 3 kasus, yaitu:

\section{Untuk $v_{1}=v_{2}$}

Andaikan $Q$ adalah penutup sisi $K_{m, n}$. Claim $Q=\left\{v_{i} \mid 1 \leq i \leq v_{1}\right\}$. Akan ditunjukan bahwa $Q$ adalah minimum penutup sisi. Berdasarkan definisi graf bipartit komplit setiap titik dilain partisi akan saling berhubungan langsung, sedangkan titik yang berada dalam satu partisi tidak saling berhubungan langsung. Sisi $v_{1} v_{2}$ dipilih oleh $Q$ maka sisi $v_{1} v_{2}$ menutup titik $v_{1}$ dan $v_{1}$, sisi $v_{2} w_{2}$ dipilih oleh $Q$ maka sisi $v_{2} w_{2}$ menutup titik $v_{2}$ dan $w_{2}$, sisi $v_{3} w_{3}$ dipilih oleh $Q$ maka sisi $v_{3} w_{3}$ menutup $v_{3}$ dan $w_{3}$, seterusnya sampai sisi $v_{m} w_{m}$ dipilih oleh $Q$ maka sisi $v_{m} w_{m}$ menutup $v_{m}$ dan $w_{m}$. Karena $m=n$ maka sisi $v_{i} w_{i}$ menutup $v_{1}+v_{2}$ titik dari $K_{m, n}$, dengan demikian semua titik dari $K_{m, n}$ telah tertutup oleh $Q$. $Q$ merupakan minimum penutup sisi dari $K_{m, n}$. Diperoleh ukuran minimum penutup sisi pada graf bipartit komplit $K_{m, n}, v_{1}=v_{2}$ adalah $\alpha_{1}\left(K_{m, n}\right)=$ $|Q|=\left|V_{1}\right|=v_{1}$

2. Saat $v_{1}<v_{2}$

Andaikan $Q$ adalah penutup sisi $K_{m, n}$,

Klaim $Q=\left\{v_{1} w_{1}, v_{2} w_{2}, v_{3} w_{3}, ., v_{m} w_{m}, v_{1} w_{m+1}, v_{1} w_{m+2}, ., v_{1} w_{n}\right\}$ Karena $v_{1}<v_{2}$ maka sisi $v_{i} w_{i}, 1 \leq i \leq \mathrm{v}_{1}$ menutup 2. $v_{1}$ titik dari $K_{m, n}$. Selanjutnya sisi $v_{1} w_{m+1} \operatorname{dipilih} Q$ maka sisi $v_{1} w_{m+1}$ menutup titik $v_{1}$ dan $w_{m+1}$, sisi $v_{1} w_{m+2}$ dipilih $Q$ maka sisi $v_{1} w_{m+2}$ menutup titik $v_{1}$ dan $w_{m+2}$, seterusnya sampai sisi $v_{1} w_{n}$ dipilih $Q$ maka sisi $v_{1} w_{n}$ menutup titik $v_{1}$ dan $w_{n}$. Sisi $v_{1} w_{m+1}, v_{1} w_{m+2}, \ldots, v_{1} w_{n}$ menutup $n-m$ titik dari $K_{m, n}$, diperoleh banyaknya titik yang tertutup oleh $Q$ adalah $\left(2 . v_{1}\right)+\left(v_{2}-v_{1}\right)=v_{1}+$ 
$v_{2}$. Dengan demikian semua titik dari $K_{m, n}$ telah tertutup oleh $Q . Q$ merupakan penutup sisi minimum dari $K_{m, n}$. Diperoleh ukuran minimum penutup sisi pada graf bipartit komplit $K_{m, n}, v_{1}<v_{2}$ adalah $\alpha_{1}\left(K_{m, n}\right)=|Q|=v_{2}$.

\section{Atau saat $v_{1}>v_{2}$}

Andaikan $Q$ adalah penutup sisi $K_{m, n}$.

Klaim $Q=\left\{v_{1} w_{1}, v_{3} w_{3}, \ldots, v_{n} w_{n}, v_{n+1} w_{1}, v_{n+2} w_{1}, \ldots, v_{m} w_{1}\right\}$

Akan dibuktikan $Q$ merupakan minimum penutup sisi. Sama seperti kasus 1, sisi $v_{i} w_{i}$ dipilih oleh $Q$. Karena $v_{1}>v_{2}$ maka sisi $v_{i} w_{i}, 1 \leq i \leq n$ menutup 2. $v_{2}$ titik dari $K_{m, n}$. Selanjutnya sisi $v_{n+1} w_{1}$ dipilih $Q$ maka sisi $v_{n+1} w_{1}$ menutup titik $v_{n+1}$ dan $w_{1}$, sisi $v_{n+2} w_{1}$ dipilih $Q$ maka $v_{n+2} w_{1}$ menutup titik $v_{n+1}$ dan $w_{1}$, seterusnya sampai sisi $v_{m} w_{1}$ dipilih $Q$ maka sisi $v_{m} w_{1}$ menutup titik $v_{m}$ dan $w_{1}$. Sisi $v_{i} w_{i}, v_{n+1} w_{1}$, $v_{n+2} w_{1}, \ldots, v_{m} w_{1}$ menutup $\left(v_{1}-v_{2}\right)=v_{2}+v_{1}$. Dengan demikian semua titik dari $K_{m, n}$ telah tertutup oleh $Q . Q$ merupakan minimum penutup sisi dari $K_{m, n}$. Diperoleh ukuran minimum penutup sisi pada graf bipartit komplit $K_{m, n}, v_{1}>v_{2}$ adalah $\alpha_{1}\left(K_{m, n}\right)=|Q|=v_{1}$.

Berdasarkan dari bukti 1, 2, dan 3 diperoleh $\alpha_{1}\left(K_{m, n}\right)=\operatorname{maks}\left\{\left|V_{1}\right|,\left|V_{2}\right|\right\}$.

\section{Kesimpulan}

Berdasarkan hasil pembahasan, maka dapat diambil kesimpulan sebagai berikut: Untuk memperoleh ukuran minimum penutup titik dan minimum penutup sisi pada graf komplit $K_{n}$ tentukan banyak titik dan sisi yang akan dicari masing-masing dengan menggunakan rumus sebagai berikut maka akan diperoleh minimum penutup titik dan minimum penutup sisi pada graf komplit $K_{n}$ yaitu: $\alpha\left(K_{n}\right)=n-1$ dan minimum penutup sisi

$$
\alpha_{1}\left(K_{n}\right)=\left\{\begin{array}{c}
\frac{n}{2}, \text { untuk } n \text { genap } \\
\frac{n+1}{2}, \text { untuk } n \text { ganjil }
\end{array}\right.
$$

Minimum penutup titik

$$
\alpha\left(K_{m, n}\right)=\min \left\{\left|V_{1}\right|,\left|V_{2}\right|\right\} \text { dan minimum penutup sisi } \alpha_{1}\left(K_{m, n}\right)=\operatorname{maks}\left\{\left|V_{1}\right|,\left|V_{2}\right|\right\}
$$

\section{Saran}


Peneliti hanya memfokuskan penelitian pada graf komplit dan graf bipartit komplit untuk peneliti selanjutnya agar meneliti penutup titik dan sisi pada graf lainnya karena masih banyak jenis graf yang layak untuk diteliti.

\section{DAFTAR PUSTAKA}

[1] Munir, Rinaldi, (2010), Matematika Diskrit, Edisi Ketiga, Bandung: Informatika

[2] Chartrand, Gery and Linda Lesniak, (1986), Graphs and Digraphs Second Edition, California: a Division of Wadsworth, Inc.

[3] Behsaz, Babak,(2008), On Minimum Vertex Covers of Generalized Petersen Graf, Vol. 40, Pages : 253-264, 2008. 